\author{
JANUARY 2017, VOLUME 5, ISSUE 1, 29 - 50 \\ E-ISSN NO: $2289-4489$
}

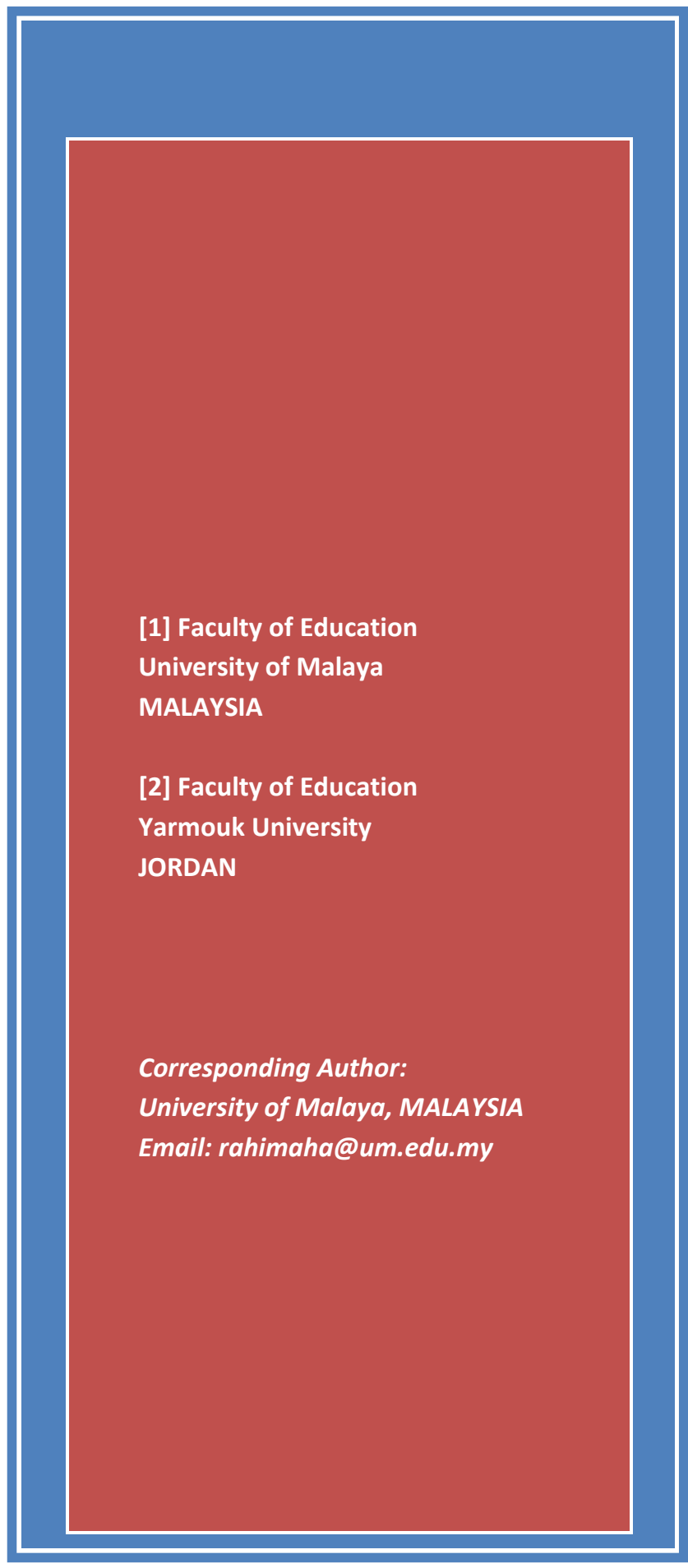

\title{
LEADERSHIP DIMENSIONS AND CREATIVITY TRAITS OF ISLAMIC SCHOOLS PRINCIPALS: A QUANTITATIVE ANALYSIS
}

Rahimah Haji Ahmad $^{1}(\mathrm{PhD})$, Ali Jubran Salleh ${ }^{2}$ \& Simin Ghavifekr ${ }^{1}(\mathrm{PhD})$

\begin{abstract}
This study explores leadership dimensions and creativity traits of the principals in the Islamic schools in Jordan. Moreover, the implications of leadership behavior and practices and creativity traits in an Islamic educational setting are discussed in this paper. Data were collected using quantitative research method. Leadership practices were measured using combination of the Leadership Practices Inventory (LPI-Self and LPIObserver), and self-developed items on the Islamic component. Creativity traits were measured using the Creativity Self-Perception Questionnaire and the Creativity Teacher Observation Questionnaire. Findings of the study revealed that principals of the Islamic schools in Jordan demonstrated positive leadership behavior in all the dimensions studied. They were also found to be creative, as they were perceived to possess all the creativity traits, both by the principals themselves as well as by the teachers. The study also found a significant correlation between the leadership dimensions and the creativity traits of principals. The results of this study indicate that the more principals demonstrated positive leadership behavior, the more creative they were.
\end{abstract}

Keywords: Indigenous student, Self-esteem, Challenges, Adaptation, Higher education, Malaysia 


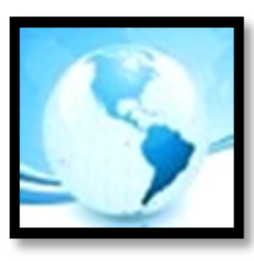

\section{MALAYSIAN ONLINE JOURNAL OF EDUCATIONAL MANAGEMENT (MOJEM)}

\section{INTRODUCTION}

Educational leadership is important for moving schools toward excellence. In this regard, "The kind and quality of leadership we have will help determine, for better or worse, the kinds of schools we have" (Elkhaldi, 1994, p. 3). Therefore, the achievement of excellence in schools is one of the main roles of principals who are considered as the educational leaders.

A positive leadership in any educational organization is crucial in creating a successful educational system that contributes to a good and happy society. It helps a nation to build its educational program in order to achieve its vision of the future. This important relationship between a good educational leadership and a successful educational system has been pointed out in several studies.

The positive impact of principals' leadership gained validation when researchers found that principal leadership is the single most powerful determinant of school effectiveness. Strong and purposive leadership by the principal is the key feature of the effective school. School principals, therefore, are responsible for school efficiency and effectiveness (Mustamin \& Yasin, 2012; Leithwood et al., 2007; Leithwood et al., 2004; Davis et al., 2005; Wildy \& Louden, 2000; James \& Vince, 2001; Datnow \& Castellano, 2001 ; Smith \& Piele, 1996 ; Sergiovanni, 1995).

Effectiveness and efficiency of the principal contribute to the success of the school. It is the effectiveness of the school leadership that creates excellence. The role of effective school leadership therefore, is crucial to the school's success (Hallinger \& Huber, 2012; Ubben \& Hughes, 1997; MacBeath, 1998; Gunter, 2001; Davis et al., 2005; Louis et al., 2010; Day et al., 2010).

It may be noted here that school principals play a vital role in making their schools effective and efficient. As the above mentioned researchers concluded, it is the responsibility of the principals to make the difference at schools by setting clear goals, modeling and leading professionally.

School leaders have to carry out several administrative roles and tasks. Successful leadership must involve a mastery of administrative and organizational skills as well as certain personal qualities. In other words, school leaders must first of all be skilful managers (Dunford et al., 2000; Mazzarella \& Grundy, 1996; Munitz, 1999; Smith \& Piele, 1996; Hallinger \& Huber, 2012; Louis et al., 2010; Day et al., 2010). This shows that the administrative and managerial skills are essential for any school leader to succeed. Therefore, some general leadership and administration theories were studied in order to apply what is relevant to the school situation.

In a study on Islamic schools in Jordan, Al-Dawoud (1996) conducted an investigation of objectives, disciplines, activities, administration, supply of resources and evaluation at private Islamic schools in Jordan. The researcher attempted to identify the main factors that affected school performance. Interestingly, he found that the importance of administration came second after objectives (p.171). These findings strongly emphasized that the Islamic schools are concerned with the role of administration by having successful principals as school leaders who are faithful, honest and committed to their work. Successful Islamic schools then will emerge only when there are effective principals leading their schools towards achieving excellence for the academic wellbeing of the students and for society in general.

Kouzes and Posner (1993) formulated a leadership theory consists of five fundamental practices including; I. Challenging the Process, II. Inspiring a Shared Vision, III. Enabling Others to Act, IV. Modeling the Way, and V. Encouraging the Heart (p. 14). The theory have been used by many scholars (Abu-Tineh et al., 2009; Hyatt, 2010; Taylor, 2002; Oumthanom, 2001; Schmiesing, 2001; Richardson et al., 1999; Morris, 2000 Muhammad, 1996; Weltman, 1995; Koster-Peterson, 1993; Nolan, 1992; Xu, 1991) that conducted research on school leadership. For example, Richardson et al. (1999) in a study about teachers' perceptions of principals' attitudes that focused on 


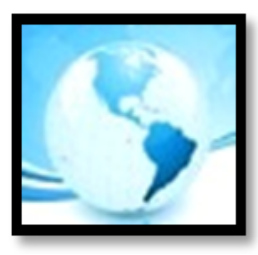

\section{MALAYSIAN ONLINE JOURNAL OF EDUCATIONAL MANAGEMENT (MOJEM)}

the characteristics of principals which make them leaders. The results showed that teachers differed from managers in their perceptions of ideal attitudes of principals. While in Kouzes and Posner theory, they identified the most important five descriptive qualities of superior leaders as honest, competent, forward-looking, inspiring and intelligent, in Richardson and the associates' study, teachers have chosen the first four of these qualities as the main characteristics of their principals to be leaders. The only difference was that teachers chose "caring" as the fifth most important attribute compared with "intelligent" for managers (in Orozco, 1999, pp. 18-19).

Similarly, Schmook (1996) also applied the Kouzes and Posner five categories of leadership in a study of schools in Florida, United States to investigate the perceptions of principals and teachers with regard to the demonstration of leadership practices (p. 8). The results show that principals of the schools clearly demonstrated the five leadership practices.

In another example, the theory of Kouzes and Posner was used by Beekun and Badawi (1999) in a book about Islamic perspective of leadership. In this book the theory has been mentioned as "one of the best models of effective leadership" (p. 115). The five leadership practices of challenging the process, inspiring a shared vision, enabling others to act, modeling the way and encouraging the heart has been highlighted as the most effective leadership practices for Muslim leaders to achieve their organizational objectives .

Since the Kouzes and Posner model represent 'one of the best models' and widely used in leadership studies, this paper utilizes the five categories of leadership of Kouzes and Posner's theory as the key leadership dimensions that examined in the study.

School leaders today face an enormous number of complex problems with educational challenges of change and these demand both leadership skills and creative solutions. Creativity is an essential factor in any organization that seeks success (Yukl, 2010; Davis et al., 2005; Sergiovanni, 1995; Short \& Greer 1997; Ubben \& Hughes, 1997).

Creativity in organizational life, as perceived by Drucker (1974), functions to provide the definition for unusual acts that enable the organization to become more effective within its defined sphere of operations. Creative leadership is an important key to reaching effectiveness and creative leaders are needed in the educational arena to improve schools.

To emphasize the importance of creativity in schools, Johnson et al. (2000) conducted a study on secondary viceprincipals. He studied the inter-relationship between the attributes of a school leader with traits of creativity and stated that "creative individuals are constantly alert to discrepancies and the need for changes in their settings" ( $\mathrm{p}$. 28). The author further discussed other attributes of creative individuals such as charisma, sense of humor, vision, risk taking, passion, open mindedness and commitment. The creative leader is seeking not to control but "to free the creative potential of others and is not so much an optimist as a believer that this liberation is possible" (p. 29).

Goertz (1991) in her study on the relationship of leader effectiveness and selected creativity traits found that effective principals in leadership positions demonstrate selected traits of creativity. She stated that "effective leadership qualities consist of more than being an administrator or a manager. Effective leadership is orchestrating the totality of the enterprise with creativity traits..." (p. 92). Goertz identified certain traits in leaders' creativity that assist them in being successful. She views creativity as "a special condition, attitude, or state of being that reflects passion for work, independence, goal setting, originality, flexibility, a wide range of interests, average or above- average intelligence and motivation " (1991, p. 3).

Later, In a study that focused on principals' leadership and creativity by Schmook (1996), Goertz's creativity traits of passion for work, independence, goal setting, originality, flexibility, wide range of interests, intelligence and motivation in assessing selected Florida schools was used. The study sought to determine and investigate the 


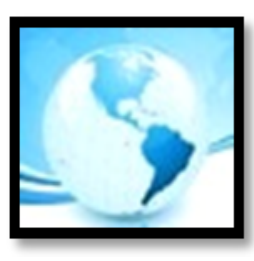

\section{MALAYSIAN ONLINE JOURNAL OF EDUCATIONAL MANAGEMENT (MOJEM)}

perceptions of principals and teachers in regard to the demonstrated creativity traits by Goertz (pp. 2-3). The study concluded that principals of Florida schools clearly demonstrated the eight creativity traits.

Similarly, many Muslim educators and researchers also considered creativity traits as important in Islam. They emphasize the importance of such creativity in educational settings as a means of enhancing effectiveness and bringing success to the organization (Abu-Tineh et al., 2009; Sweidan \& Adlouni, 2002; Al-Sorour, 2002; Al-Athm, 2002; Al-Hammadi, 1996; Al-Safi, 1997; Yousif, 1999; Eisawi, 1990; Al-Mazeidy, 1993).

As Goertz's theory is one of the common theories of creativity traits that have been recognized by many researchers, this study utilized the eight creativity traits that examined in this paper.

The above-mentioned studies on leadership and creativity show that sound educational leadership is important for success in schools. The objectives of schools can be achieved if there is proper and effective educational leadership and there is an effective principal. Creativity plays a complementary role and it will enhance and foster the success of the school principals.

Consideration of the above factors provides strong justification for this study, which is an effort to enrich the Islamic corpus on educational leadership. The focus on the Islamic school principals in Jordan was for the following reasons:

I. The importance of the Islamic schools in Jordan is distinguished by their emphasis on focusing more on an Islamic foundation, its culture and morals.

II. The rapid growth of these schools in all districts in Jordan, which shows people's acceptance of these schools. This was the sign of the success of the Islamic schools in Jordan that has been proven by their increasing student enrolment. This was also the reason for making them the most important and the leading schools in Jordan.

III. With the exception of a few studies, research on Islamic schools in general and in Jordan in particular has not received much attention.

IV. With the exception of a few articles and studies, work on leadership and creativity from an Islamic perspective is critically lacking.

V. The need to identify the Islamic features of educational leadership and creativity. Muslim intellectuals should make more effort to understand the issue of educational leadership and creativity in Islam. Such a goal can be achieved if Islamic organizations are studied. The studying of Islamic schools can considerably help us in understanding how such organization may best thrive.

This study proposes to examine educational leadership and creativity in the Islamic schools in Jordan in regard to the demonstrated leadership practices and creativity traits of principals in the schools concerned.

The main objective of this study is to explore the leadership practices and creativity traits of Islamic school principals in Jordan. More specifically, the study focuses on describing the leadership practices and creativity traits of the concerned principals. In addition it examines the relationship between the leadership practices of principals and their creativity traits. Accordingly, the following questions have been investigated in the study: 
1. To what extent do principals in Islamic schools in Jordan demonstrate leadership practices as reported by principals and perceived by their teachers?

2. To what extent do principals in Islamic schools in Jordan demonstrate creativity traits as reported by principals and perceived by their teachers?

3. Is there any relationship between the leadership practices of principals and their creativity traits at the Islamic schools in Jordan as reported by principals themselves and perceived by the teachers?

\section{METHODOLOGY}

\section{Population and Sample}

The population of this quantitative study comprise of principals and teachers from 86 primary and secondary Islamic schools in Jordan. There are 1820 teachers serving these schools (Ministry of Education Jordan, 2002). Details of the Islamic schools in Jordan are presented in Table 1.

The table below, shows that there were 86 Islamic schools in Jordan. Of these, 80 schools participated in the study. Ten schools that participated in the pilot study for this research were excluded from the actual study. The other 70 schools participated in the study. As a result, 93 percent of the Islamic schools in Jordan participated in the study.

Table 1

Distribution of Islamic Schools in Jordan

\begin{tabular}{lllc}
\hline City & $\begin{array}{l}\text { No. of Islamic } \\
\text { Schools }\end{array}$ & Schools Studied & Percentage \\
\hline Amman & 54 & 49 & 90.7 \\
Madaba & 4 & 4 & 100 \\
Zarqa & 8 & 7 & 87.5 \\
Balqa & 5 & 5 & 100 \\
Irbid & 5 & 5 & 100 \\
Ajloun & 1 & 1 & 100 \\
Mafraq & 2 & 2 & 100 \\
Ramtha & 1 & 1 & 100 \\
Karak & 3 & 3 & 100 \\
Ma'an & 1 & 1 & 100 \\
Aqaba & 2 & 2 & 100 \\
\hline & & & 93 \\
Total & 86 & 80 & \\
\hline
\end{tabular}

All principals of the Islamic schools were approached to participate in the research. As for the teachers, a sample of 20 was selected randomly from each school that had more than 20 teachers, and all teachers from schools that had 20 or less teachers participated in the study. A systematic sampling method was used as one "that approximates a simple random sample" (Guy et al., 1987). To obtain a systematic sample, all teachers from schools that had more than 20 were listed. Then, the desired sample size, that is 20, was divided into the teachers' number to give the increment value, labeled $\mathrm{N}$. The sample selected was composed of every Nth teacher from the list. 


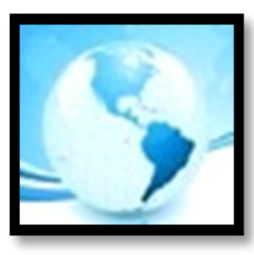

\section{Instrumentation}

Two adapted questionnaires for leadership practices and creativity traits were used to collect the data from the subjects. The two questionnaires used in the study are as follow:

- $\quad$ The Leadership Practices Inventory (LPI-Self) and Leadership Practices Inventory (LPI-Observer)

These are adapted instruments originally developed by Kouzes and Posner (1997) as empirical measures of the conceptual leadership framework generated from the case studies of 1,100 managers, personal best experiences as leaders. There are two forms of the Inventory: Leadership Practices Inventory (LPI-Self) (Kouzes \& Posner ,1997), describing the leadership behavior from the first person, and Leadership Practices Inventory (LPI- Observer) (Kouzes \& Posner, 1997) describing the leadership behavior from another person's view. Both instruments have been used in studies involving over 35,000 managers and their subordinates. Permission to use the questionnaire for this study was granted by Posner.

In order to make this questionnaire more appropriate for the Islamic school setting, the questionnaire was adapted; it was decided to add five dimensions of leadership to those five of Kouzes and Posner. The five new dimensions are including; Observing Islamic Value System, Building a Positive Culture, Managing and leading, Relating with Students and Relating with Community. Thirty two items were constructed and added to the original questionnaire that measures the dimensions of challenging the Process, Inspiring a Shared Vision, Enabling Others to Act, Modeling the Way and Encouraging the Heart. The 30 items of the original five dimensions were reduced to 15 items. The ten dimensions of the adapted questionnaire with their items are as follow:

I. Observing Islamic Value System (10 items),

II. Building a Positive Culture (6 items),

III. Managing and leading (10 items),

IV. Relating with Students (3 items),

V. Relating with Community (3 items),

VI. Challenging the Process (3 items),

VII. Inspiring a Shared Vision (3 items),

VIII. Enabling Others to Act (3 items),

IX. Modeling the Way (3 items),

$X$. Encouraging the Heart (3 items).

- $\quad$ The Creativity Self-Perception Questionnaire (CSPQ) and Creativity Teacher Observation Questionnaire (CTOQ)

The adapted instruments originally developed by Goertz (1991) based on the selected traits of creativity as they relate to the variables of Passion for Work, Independence, Originality, Flexibility, Wide Range of Interests, Goal Setting, Intelligence and Creativity, and Motivation. The CSPQ is used to assess principals' perceptions of their creativity while CTOQ is used to determine teachers' perceptions of the principals' creativity. Permission to use the questionnaire for the study was granted by Goertz (1991).

In order to make this questionnaire more appropriate for the study setting (i.e. Islamic schools), the questionnaire was adapted. It was decided to employ the eight main dimensions of the original questionnaire with some changes. The 47 items of the original eight dimensions were reduced to 20 and two more items were added to make them more appropriate to the educational settings of Islamic schools. The eight dimensions of the adapted questionnaire with their items are: 


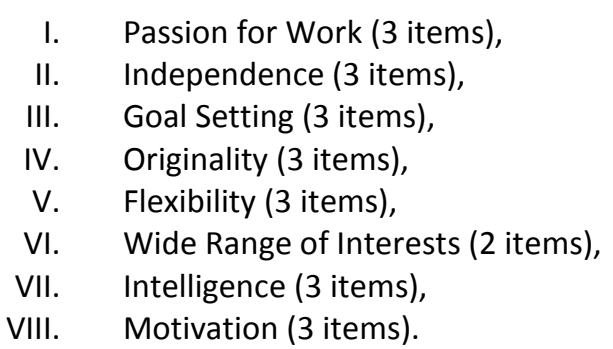

\section{Pilot Testing of Questionnaires}

To conduct the pilot study, ten schools located in the capital, Amman, were randomly selected. These schools comprised both primary and secondary and both male and female teachers. These schools were excluded from the actual study. A total of 139 questionnaires were distributed to a sample of teachers in each school in the pilot study. The sample was the same of the actual study which is 20 teachers from each school that have more than 20 teachers to be selected randomly and all teachers of those schools that have 20 or fewer teachers were taken to participate in the study. Some 98 questionnaires were returned. However, only 93 questionnaires were used. The rest were excluded from the analysis because of incomplete information and unanswered items.

A reliability test was conducted on the pilot questionnaires of Leadership Practices Inventory (LPI-Self) and (LPIObserver) and the Creativity Self-Perception Questionnaires CSPQ and Creativity Teacher Observation Questionnaires (CTOQ).

In order to examine the reliability of the Leadership Practices Inventory (LPI-Self) and (LPI-Observer), Cronbach's alpha coefficient was used to measure the internal consistency of the items within each dimension of leadership. Table 2 presents the alpha reliability for the ten leadership dimensions of the questionnaire.

Table 2

Reliability of the Ten Leadership Dimensions (LPI-Self) and (LPI-Observer) (N=93)

Leadership Dimensions

Coefficient alpha

\begin{tabular}{ll}
\hline Observing Islamic Value System & .86 \\
Building a Positive Culture & .88 \\
Managing and leading & .83 \\
Relating with Students & .73 \\
Relating with Community & .79 \\
Challenging the Process & .71 \\
Inspiring a Shared Vision & .63 \\
Enabling Others to Act & .75 \\
Modeling the Way & .89 \\
Encouraging the Heart & .79 \\
\hline
\end{tabular}

Table 2 shows that reliability coefficients were above .80 for four dimensions and above .71 for five other dimensions. The lowest reliability coefficient was found in Inspiring a Shared Vision $(\alpha=.63)$. 
In order to check the reliability of the Creativity Self-Perception Questionnaires CSPQ and Creativity Teacher Observation Questionnaires (CTOQ), Cronbach's alpha coefficient was also used to measure the internal consistency of the items within each creativity trait. Table 3 presents the alpha reliability for the eight creativity traits of the questionnaire.

Table 3

Reliability of the Eight Creativity traits (CSPQ) and (CTOQ) $(\mathbf{N}=93)$

Creativity Traits Coefficient Alpha

\begin{tabular}{ll}
\hline Passion for Work & .81 \\
Independence & .72 \\
Goal Setting & .79 \\
Originality & .84 \\
Flexibility & .88 \\
Wide Range of Interests & .62 \\
Intelligence & .80 \\
Motivation & .57 \\
\hline
\end{tabular}

The table above, shows reliability coefficients were above .80 for four traits and above .71 for two other traits. The lowest reliability coefficients were in Wide Range of Interests $(\alpha=.62)$ and Motivation $(\alpha=.57)$. It will be relevant to mention here that the original questionnaire has two traits with low alpha values. These are Goal Setting ( $\alpha=$ .13) and Independence ( $\alpha=.59)$ (Schmook, 1996, p. 56).

\section{Data Analysis}

Data gathered from the Leadership Practices Inventory (LPI-Self) and (LPI-Observer) were imported into the Statistical Package for the Social Sciences (SPSS) to analyze and summarize the (LPI-Self and LPI-Observer) scores for each principal for the ten leadership practices. Data from the Creativity Self-Perception Questionnaire (CSPQ) and Creativity Teacher Observation Questionnaire (СTOQ) were also imported into the Statistical Package for the Social Sciences (SPSS) to analyze and summarize the (CSPQ and CTOQ) scores for each of the eight creativity traits.

The development of Leadership Practices Inventory (LPI-Self) and (LPI-Observer) and Creativity Self-Perception Questionnaire (CSPQ) and Creativity Teacher Observation Questionnaire (CTOQ) scale scores were clear and the mean scale scores were determined in order to answer all of the research questions. Frequencies, percentages, and Pearson product-moment correlation coefficient were used to answer the research questions. Responses to all questionnaires were measured using a 5-point Likert scale as follows: 1 . Rarely, 2. Once in a While, 3. Sometimes, 4. Fairly Often and 5. Very Frequently.

\section{Demographic Data of Respondents}

A total of 70 principals and 889 teachers from 70 Islamic schools in Jordan participated in the study. The principals' and teachers' demographic data are displayed in Table 4 and 5. 


\section{Principals' Demographic Data:}

Table 4 presents the distribution of the principals according to background characteristics. As can be seen, the majority; 72.9 percent (51) of the principals are females, while 27.1 percent (19) are males.

Expressed otherwise, female principals outnumber males. As can be seen from the table, the majority of the respondents or 61.4 percent (43) were from primary schools while 38.6 percent (27) were from secondary schools. Most of the principals in primary schools are females. In addition, some of the schools are co-educational for the first three grades. In Jordan, male principals are prohibited from working in co-educational schools. Female principals are allowed also to head such schools. As can be noted here also, most of the students in the Islamic schools were girls.

It is also shows that the majority of the principals were between the ages of 25-34 and 35-44 years. These represent 28.6 percent and 32.9 percent of the sample respectively. On the other hand, 19 principals (27.1\%) were between the ages of $45-54$ years and only 11.4 percent (8) are above 55 years old. It can be noted that the majority of the principals (61.5\%) were younger than 44 years old.

A majority of the principals (51.4\%) reported having a Bachelor degree. This category was followed by 41.4 percent with diploma degree. Only 7.1 percent reported having completed a Master's degree. None of the Islamic school principals held a Ph.D.

Table 4

Distribution of Principals According to Background Characteristics

$(\mathrm{N}=70)$

\begin{tabular}{|c|c|c|}
\hline Characteristics & Frequency & Percentage \\
\hline \multicolumn{3}{|l|}{ Gender } \\
\hline Male & 19 & 27.1 \\
\hline Female & 51 & 72.9 \\
\hline \multicolumn{3}{|l|}{ Age } \\
\hline $25-34$ years & 20 & 28.6 \\
\hline $35-44$ years & 23 & 32.9 \\
\hline $45-54$ years & 19 & 27.1 \\
\hline 55 years and above & 8 & 11.4 \\
\hline \multicolumn{3}{|l|}{ Types of Schools } \\
\hline Primary & 43 & 61.4 \\
\hline Secondary & 27 & 38.6 \\
\hline \multicolumn{3}{|l|}{ Educational Level } \\
\hline Diploma & 29 & 41.4 \\
\hline Bachelor & 36 & 51.4 \\
\hline Masters & 5 & 7.2 \\
\hline \multicolumn{3}{|l|}{ Experience in Education } \\
\hline 4- 10 years & 20 & 28.6 \\
\hline $11-15$ years & 11 & 15.7 \\
\hline
\end{tabular}




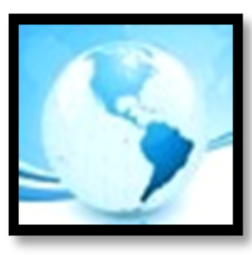

16-20 years

21 years and above

\section{Experience as Principal}

Less than a year

1-5 years

6-10 years

11 years and above

MALAYSIAN ONLINE JOURNAL OF

EDUCATIONAL MANAGEMENT

(MOJEM)

16

23

4

32

17

17
22.9

32.9

5.7

45.7

24.3

24.3

Experience as a Principal at the Current School

Less than a year

1-5 years

6-10 years

11 years and above
7

39

16

8
10

55.7

22.9

11.4

Among the principals, 28.6 percent (20) indicated that they have had 4-10 years of experience in education. 15.7 percent (11) have had 11-15 years of experience, 22.9 percent (16) of the principals have had 16-20 years of experience and 32.9 percent (23) have had more than 21 years of experience in education. It is clear that the majority of principals $(55.8 \%)$ had more than 16 years in education.

Regarding their experience as principals, the majority of them, that is 45.7 percent (32) indicated they had had 1-5 years of experience, 24.3 percent (17) had had 6-10 years of experience and 24.3 percent (17) had more than 11 years of experience as principal. However, only 5.7 percent (4) have indicated they had less than a year as principal. As can be noted, 51.4 percent of the principals had less than 5 years of experience as a principal.

Similarly, the majority of the principals studied, that is 55.7 percent (39) had had 1-5 years of experience as a principal at their present school, 22.9 percent (16) had had 6-10 years while 11.4 percent (8) had had more than 11 years of experience at their current school. However, only 10 percent (7) indicated they had had less than a year as principal in the school being studied. Once again, the majority of the principals (65.7\%) had had less than 5 years as a principal in the studied schools.

In sum, of the 70 principals, the majority was young, that is 61.5 percent were below 44 years old with almost 30 percent below 34 years. Although the majority of 55.7 percent had more than 16 years in education, 51.4 percent had less than 5 years as a principal. 65.7 percent had less than 5 years as a principal in the studied schools.

\section{Teachers' Demographic Data:}

Table 5 presents the background characteristics of the sample of teachers in the study. As can be seen, an overwhelming majority of the respondents $(72.9 \%)$ were females. As mentioned earlier, there are more Islamic primary schools than Islamic secondary schools, as well as more girls' schools at the primary level. Male teachers are prohibited from working in the girls' schools. Unlike males, female teachers are only allowed to teach at the coeducational schools for the first three grades of schooling. Clearly, female teachers will outnumber male teachers. 
As mentioned above, the majority of 60.5 percent (538) of the responding teachers indicated that they were from primary schools and 39.5 percent (351) were from secondary schools. This is because most of the Islamic schools are primary as explained earlier.

It is also shown that almost 60 percent of the teachers were within the 20-30 years age category. This was followed by teachers falling into the 31-40 years category, representing 30.4 percent of the respondents. Only 5.7 percent and 4.6 percent respectively were within $41-50$ years and 51 years and above respectively. It is worth mentioning that most of teachers or 89.7 percent were below 40 years old and only 10.3 percent were above 40 years.

Concerning the respondents' academic qualifications, 52.1 percent hold a Bachelor's degree, while 46.0 percent have diplomas. Surprisingly, less than 2 percent of the teachers have master's degree. As for the teachers' experience in education, more than half (52.6\%) indicated that they have educational experience between 1 and 5 years, while 23.1 percent reported that they have 6-10 years of experience. Fewer teachers reported having 11-15 years (12.6\%), and 16 years and above (i.e., $11.7 \%$ ) of experience. It can be noted that the majority (i.e., $75.7 \%$ ) had less than 10 years in education.

Table 5

Distribution of Teachers According to Background Characteristics

$(\mathrm{N}=889)$

\begin{tabular}{lcc}
\hline Characteristics & Frequency & Percentage \\
\hline Gender & & 27.1 \\
Male & 241 & 72.9 \\
Female & 648 & \\
Age & & 59.3 \\
20-30 years & 527 & 30.4 \\
31-40 years & 270 & 5.7 \\
41-50 years & 51 & 4.6 \\
50 years and above & 41 & \\
& & 60.5 \\
Types of Schools & & 39.5 \\
Primary & 538 & \\
Secondary & 351 & 46 \\
& & 52.1 \\
Educational Level & & 1.9 \\
Diploma & 409 & \\
Bachelor & 463 & 11.7 \\
Master's & 17 & 52.6 \\
Experience in Education & & 23.1 \\
1-5 years & 104 & \\
6-10 years & 468 & \\
11-15 years & 205 & \\
From 16 years & 12 & \\
& & \\
& &
\end{tabular}




\author{
Experience in Teaching \\ at the Current School \\ Less than a year \\ 1-5 years \\ 6-10 years \\ 11 years and above
}

$\begin{array}{ll}121 & 13.6 \\ 516 & 58 \\ 150 & 16.9 \\ 102 & 11.5\end{array}$

Finally, among teachers, the majority of them or 58 percent (516) indicated they had had 1-5 years of experience in teaching at the school; 16.9 percent (150) of the teachers had had 6-10 years of experience and only 11.5 percent (102) had had more than 11 years as an experience in teaching at the school. However, only 13.6 percent (121) have indicated they had had less than a year in teaching at the school studied. It can be noted that most of the teachers $(71.6 \%)$ had had less than 5 years in teaching at the schools studied.

In sum, the majority of the 889 teachers were young that is 89.7 percent were below 40 years old. This might explain why the majority (i.e., $75.7 \%$ ) had had less than 10 years in education and 71.6 percent had had less than 5 years of teaching at the schools studied.

\section{RESULTS}

\section{The Extent of the Principals' Leadership Practices in Islamic Schools}

The data related to the first research question, were obtained from principals' and teachers' responses to the Leadership Practices Inventory (LPI-Self) and (LPI-Observer). The principals were requested to answer whether they perform the ten leadership dimensions namely; Observing Islamic Value System, Building a Positive Culture, Managing and Leading, Relating with Students, Relating with Community, Challenging the Process, Inspiring a Shared Vision, Enabling Others to Act, Modeling the Way and Encouraging the Heart. Moreover, teachers were requested to answer whether their principals performed the identified ten leadership dimensions. The responses were rated on a five-point scale of; 1 . Rarely, 2 . Once in a While, 3. Sometimes, 4. Fairly Often, and 5. Very Frequently.

However, in order to focus on the positive and negative results, combined percentages (Fairly Often - Very Frequently) and (Rarely- Once in a While) were calculated. In order to answer this question, responses were analyzed using frequencies and percentages for each of the ten dimensions of the Leadership Practices Inventory.

\section{- Principals' Perceptions of Their Leadership Practices by Dimension:}

Analysis of the results from the Leadership Practices Inventory (LPI-Self) reveals that the principals perceived themselves positively in all the dimensions. The percentages ranged from 79.6 percent (the lowest) to 94.2 percent (the highest) and were overall quite high. While Challenging the Process dimension received the lowest percentage, Relating with Students dimension was perceived as the highest. Details of the principals' perceptions for the ten leadership dimensions are displayed in Table 6.

Table 6 shows that the Relating with Students dimension was perceived as having the highest percentage $(94.2 \%)$ as practiced fairly often or very frequently by the principals among the ten leadership dimensions. This was followed by Observing Islamic Value System dimension that scored 93.3 percent. With an almost similar percentage, the Modeling the Way got 92.9 percent as perceived fairly often or very frequently by the principals. 
Enabling Others to Act came in the fourth with 89.5 percent followed by Building a Positive Culture (88.6 \%). Sixth came, Inspiring a Shared Vision ( $88.1 \%$ ) followed by Relating with Community (87.6 \%). Encouraging the Hearts came next $(87.1 \%)$, followed by Managing and Leading that came in ninth $(85.4 \%)$ followed by the final dimension that is Challenging the Process (79.6\%).

Table 6

Principals' Perceptions of Their Leadership Practices by Dimension $(\mathrm{N}=70)$

\begin{tabular}{|c|c|c|c|c|c|}
\hline Dimensions & Rarely & $\begin{array}{l}\text { Once in } \\
\text { a While }\end{array}$ & $\begin{array}{l}\text { Some- } \\
\text { times }\end{array}$ & Fairly Often & $\begin{array}{l}\text { Very } \\
\text { Frequently }\end{array}$ \\
\hline $\begin{array}{l}\text { Observing Islamic } \\
\text { Value System }\end{array}$ & $\begin{array}{l}.4 \\
(3)\end{array}$ & $\begin{array}{l}4 \\
(3)\end{array}$ & $\begin{array}{l}5.9 \\
(41)\end{array}$ & $\begin{array}{l}35.4 \\
(248)\end{array}$ & $\begin{array}{l}57.9 \\
(405)\end{array}$ \\
\hline Building a Positive Culture & $\begin{array}{l}.2 \\
(1)\end{array}$ & $\begin{array}{l}.7 \\
(3)\end{array}$ & $\begin{array}{l}10.5 \\
(44)\end{array}$ & $\begin{array}{l}37.4 \\
(157)\end{array}$ & $\begin{array}{l}51.2 \\
(215)\end{array}$ \\
\hline $\begin{array}{l}\text { Managing and } \\
\text { Leading }\end{array}$ & $\begin{array}{l}.4 \\
(3)\end{array}$ & $\begin{array}{l}2 \\
(14)\end{array}$ & $\begin{array}{l}12.1 \\
(85)\end{array}$ & $\begin{array}{l}45.7 \\
(320)\end{array}$ & $\begin{array}{l}39.7 \\
(278)\end{array}$ \\
\hline Relating with Students & $\begin{array}{l}.5 \\
(1)\end{array}$ & $\begin{array}{l}.5 \\
(1)\end{array}$ & $\begin{array}{l}4.8 \\
(10)\end{array}$ & $\begin{array}{l}45.2 \\
(95)\end{array}$ & $\begin{array}{l}49 \\
(103)\end{array}$ \\
\hline $\begin{array}{l}\text { Relating with } \\
\text { Community }\end{array}$ & $\begin{array}{l}1 \\
(2)\end{array}$ & $\begin{array}{l}0 \\
(0)\end{array}$ & $\begin{array}{l}11.4 \\
(24)\end{array}$ & $\begin{array}{l}48.6 \\
(102)\end{array}$ & $\begin{array}{l}39 \\
(82)\end{array}$ \\
\hline Challenging the Process & $\begin{array}{l}1.9 \\
(4)\end{array}$ & $\begin{array}{l}1.9 \\
(4)\end{array}$ & $\begin{array}{l}16.7 \\
(35)\end{array}$ & $\begin{array}{l}46.7 \\
(98)\end{array}$ & $\begin{array}{l}32.9 \\
(69)\end{array}$ \\
\hline $\begin{array}{l}\text { Inspiring a Shared } \\
\text { Vision }\end{array}$ & $\begin{array}{l}0 \\
(0)\end{array}$ & $\begin{array}{l}1.4 \\
\text { (3) }\end{array}$ & $\begin{array}{l}10.5 \\
(22)\end{array}$ & $\begin{array}{l}32.9 \\
(69)\end{array}$ & $\begin{array}{l}55.2 \\
(116)\end{array}$ \\
\hline Enabling Others to Act & $\begin{array}{l}.5 \\
(1)\end{array}$ & $\begin{array}{l}.5 \\
(1)\end{array}$ & $\begin{array}{l}9.5 \\
(20)\end{array}$ & $\begin{array}{l}37.1 \\
(78)\end{array}$ & $\begin{array}{l}52.4 \\
(110)\end{array}$ \\
\hline Modeling the Way & $\begin{array}{l}0 \\
(0)\end{array}$ & $\begin{array}{l}.5 \\
(1)\end{array}$ & $\begin{array}{l}6.7 \\
(14)\end{array}$ & $\begin{array}{l}38.1 \\
(80)\end{array}$ & $\begin{array}{l}54.8 \\
(115)\end{array}$ \\
\hline Encouraging the Heart & $\begin{array}{l}.5 \\
(1)\end{array}$ & $\begin{array}{l}2.3 \\
(5)\end{array}$ & $\begin{array}{l}10 \\
(21)\end{array}$ & $\begin{array}{l}44.3 \\
(93)\end{array}$ & $\begin{array}{l}42.8 \\
(90)\end{array}$ \\
\hline
\end{tabular}

Note. Numbers in bracket indicate frequencies

It is relevant to note here that Principals' Relating with Students dimension received the highest percentage (94.2 $\%)$ among all. The principals appeared to agree on the importance of having parent-child relationships with their students. The reason for that might be because the overall philosophy of Islamic schools emphasizes students' well-being. Students as the Islamic schools believe, are the main reason of the establishment of the Islamic schools (Al-Athm 2002). Before looking at the economic factor, students are the main concern for the schools. 
The second and third most important dimensions, Observing Islamic Value System and Modeling the Way, came next with identical percentages of 93.3 percent and 92.9 percent respectively. It is clear here that principals perceived themselves highly as models for their staff. At the same time, they emphasized the importance of having the main characteristics of being a Muslim leader for an educational organization. It is interesting to note that these two dimensions scored an almost similarly high percentage. This indicates how closely they relate to each other. The school principals cannot be models without having certain characteristics that are included in the Islamic value system.

\section{- $\quad$ Teachers' Perceptions of Principals' Leadership Practices by Dimension}

Analysis of the results from the Leadership Practices Inventory (LPI-Observer) revealed that teachers perceived their principals positively in all the dimensions with slightly lower percentages than the principals perceived in themselves. They ranged from 67.4 percent; (the lowest) to 84.3 percent; (the highest) and are of a generally acceptable level. While Challenging the Process dimension has got the lowest percentage, Relating with Students dimension was the highest among all leadership dimensions. Details of the teachers' perceptions for the ten leadership dimensions of their principals are displayed in Table 7.

As shows in Table 7, the Relating with Students dimension as demonstrated by principals fairly often or very frequently was the highest (84.3 percent) among the ten leadership dimensions as perceived by their teachers. This was followed by the Observing Islamic Value System dimension (82.9\%). Modeling the way came in the third with 81.4 percent followed by Relating with Community (78.5\%). Building a Positive Culture came next with a percentage of 77.7. Sixth, Inspiring a Shared Vision with 77.2 percent followed by Enabling Others to Act with 75.9 percent. Managing and Leading came next with 74.4 percent. Ninth came, Encouraging the Hearts with 72.4 percent followed by the final dimension of Challenging the Process with 67.4 percent.

Table 7

Teachers' Perceptions of Principals' Leadership Practices by Dimension $(\mathrm{N}=889)$

\begin{tabular}{|c|c|c|c|c|c|}
\hline Dimensions & Rarely & $\begin{array}{l}\text { Once in } \\
\text { a While }\end{array}$ & $\begin{array}{l}\text { Some- } \\
\text { times }\end{array}$ & Fairly Often & $\begin{array}{l}\text { Very } \\
\text { Frequently }\end{array}$ \\
\hline Observing Islamic & 2.4 & 2.8 & 11.9 & 32.9 & 49.97 \\
\hline Value System & $(210)$ & $(254)$ & $(1055)$ & $(2928)$ & (4443) \\
\hline \multirow[t]{2}{*}{ Building a Positive Culture } & 3.3 & 4.2 & 14.7 & 33 & 44.7 \\
\hline & (174) & $(224)$ & (787) & $(1761)$ & $(2383)$ \\
\hline \multirow[t]{2}{*}{ Managing and Leading } & 4.3 & 4.7 & 16.6 & 35.9 & 38.5 \\
\hline & (383) & $(407)$ & (1479) & (3196) & (3425) \\
\hline \multirow[t]{2}{*}{ Relating with Students } & 1.4 & 1.9 & 12.4 & 31.3 & 53 \\
\hline & (38) & (52) & $(330)$ & (834) & (1413) \\
\hline Relating with & 2.1 & 3.9 & 15.6 & 36.7 & 41.8 \\
\hline Community & (56) & (103) & (415) & (978) & $(1115)$ \\
\hline
\end{tabular}




\begin{tabular}{|c|c|c|c|c|c|}
\hline Challenging the Process & $\begin{array}{l}5.5 \\
(146)\end{array}$ & $\begin{array}{l}7.3 \\
(196)\end{array}$ & $\begin{array}{l}19.8 \\
(528)\end{array}$ & $\begin{array}{l}33.1 \\
(882)\end{array}$ & $\begin{array}{l}34.3 \\
(915)\end{array}$ \\
\hline $\begin{array}{l}\text { Inspiring a Shared } \\
\text { Vision }\end{array}$ & $\begin{array}{l}4.8 \\
(127)\end{array}$ & $\begin{array}{l}4.5 \\
(120)\end{array}$ & $\begin{array}{l}13.5 \\
(360)\end{array}$ & $\begin{array}{l}31.2 \\
(833)\end{array}$ & $\begin{array}{l}46 \\
(1227)\end{array}$ \\
\hline Enabling Others to Act & $\begin{array}{l}3.1 \\
(83)\end{array}$ & $\begin{array}{l}4.7 \\
(125)\end{array}$ & $\begin{array}{l}16.3 \\
(434)\end{array}$ & $\begin{array}{l}33.2 \\
(886)\end{array}$ & $\begin{array}{l}42.7 \\
(1139)\end{array}$ \\
\hline Modeling the Way & $\begin{array}{l}2.3 \\
(62)\end{array}$ & $\begin{array}{l}3.1 \\
(83)\end{array}$ & $\begin{array}{l}13 \\
(348)\end{array}$ & $\begin{array}{l}34 \\
(908)\end{array}$ & $\begin{array}{l}47.4 \\
(1266)\end{array}$ \\
\hline Encouraging the Heart & $\begin{array}{l}4.4 \\
(117)\end{array}$ & $\begin{array}{l}5 \\
(134)\end{array}$ & $\begin{array}{l}18.2 \\
(584)\end{array}$ & $\begin{array}{l}35.5 \\
(946)\end{array}$ & $\begin{array}{l}36.9 \\
(985)\end{array}$ \\
\hline
\end{tabular}

It can be noticed that Relating with Students dimension has got the highest percentage (84.3 \%) among all. Teachers believed that their principals realized the importance of having parent-child relationships with their students. Teachers in this regard emphasized the principals' awareness of strengthening such positive relations that enhance the overall educational process at the school. Teachers also believe that their principals were performing and practicing the philosophy of the Islamic school that pays a great attention to the students' wellbeing.

It is interesting to note here that Observing Islamic Value System came next with the percentage of 82.9 percent followed by the Modeling the Way dimension (81.4 \%) as perceived by teachers. Teachers in this regard emphasized the importance of having several important characteristics as a core of being a good Muslim principal. They looked at their principals as models in their behavior at the school in general. It could be indicated that teachers viewed their principals as models when they displayed those important characteristics and qualities that enable them to be good and successful Muslim leaders for Islamic organizations.

\section{The Extent Of The Principals' Creativity Traits In Islamic Schools}

The data related to the second research question were obtained from principals' and teachers' responses to the Leadership Creativity Questionnaire (Self) and (Observer). Principals were requested to answer whether they performed the eight creativity traits. Teachers were requested to answer whether their principals performed the identified eight creativity traits. In order to answer this question, frequencies and percentages for each of the eight creativity traits were used.

\section{- Principals' Perceptions of Their Creativity Traits by Dimension}

Analysis of the results from the Creativity Self-Perception Questionnaire (CSPQ) reveals that principals demonstrated all creativity traits positively. The percentages ranged from 75 percent (the lowest) to 94.3 percent (the highest) and are reasonably high overall. While the trait of Wide Range of Interests got the lowest percentage, Passion for Work was perceived as the highest. Details of the principals' perceptions for the eight creativity traits are displayed in Table 8. 


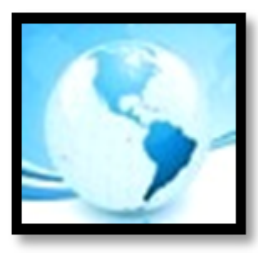

Table 8

Principals' Perceptions of Their Creativity Traits by Dimension ( $\mathrm{N}=70)$

\begin{tabular}{|c|c|c|c|c|c|}
\hline Traits & Rarely & $\begin{array}{l}\text { Once in a } \\
\text { While }\end{array}$ & $\begin{array}{l}\text { Some- } \\
\text { Times }\end{array}$ & Fairly Often & $\begin{array}{l}\text { Very } \\
\text { Frequently }\end{array}$ \\
\hline Passion for Work & $\begin{array}{l}.5 \\
(1)\end{array}$ & $\begin{array}{l}0 \\
(0)\end{array}$ & $\begin{array}{l}5.2 \\
(11)\end{array}$ & $\begin{array}{l}34.3 \\
(72)\end{array}$ & $\begin{array}{l}60 \\
(126)\end{array}$ \\
\hline Independence & $\begin{array}{l}.4 \\
(3)\end{array}$ & $\begin{array}{l}1.9 \\
(4)\end{array}$ & $\begin{array}{l}13.8 \\
(29)\end{array}$ & $\begin{array}{l}40 \\
(84)\end{array}$ & $\begin{array}{l}42.9 \\
(90)\end{array}$ \\
\hline Goal Setting & $\begin{array}{l}0 \\
(0)\end{array}$ & $\begin{array}{l}.5 \\
(1)\end{array}$ & $\begin{array}{l}10.5 \\
(22)\end{array}$ & $\begin{array}{l}42.4 \\
(89)\end{array}$ & $\begin{array}{l}46.7 \\
(98)\end{array}$ \\
\hline Originality & $\begin{array}{l}1 \\
(2)\end{array}$ & $\begin{array}{l}1.4 \\
(3)\end{array}$ & $\begin{array}{l}9.5 \\
(20)\end{array}$ & $\begin{array}{l}38.1 \\
(80)\end{array}$ & $\begin{array}{l}50 \\
(105)\end{array}$ \\
\hline Flexibility & $\begin{array}{l}0 \\
(0)\end{array}$ & $\begin{array}{l}0 \\
(0)\end{array}$ & $\begin{array}{l}10 \\
(21)\end{array}$ & $\begin{array}{l}53.8 \\
(113)\end{array}$ & $\begin{array}{l}36.2 \\
(76)\end{array}$ \\
\hline Wide Range of Interests & $\begin{array}{l}2.9 \\
(4)\end{array}$ & $\begin{array}{l}2.9 \\
(4)\end{array}$ & $\begin{array}{l}19.2 \\
(27)\end{array}$ & $\begin{array}{l}44.3 \\
(62)\end{array}$ & $\begin{array}{l}30.7 \\
(43)\end{array}$ \\
\hline Intelligence & $\begin{array}{l}0 \\
(0)\end{array}$ & $\begin{array}{l}.7 \\
(1)\end{array}$ & $\begin{array}{l}15 \\
(21)\end{array}$ & $\begin{array}{l}46.4 \\
(65)\end{array}$ & $\begin{array}{l}37.9 \\
(53)\end{array}$ \\
\hline Motivation & $\begin{array}{l}0 \\
(0)\end{array}$ & $\begin{array}{l}4.7 \\
(10)\end{array}$ & $\begin{array}{l}16.7 \\
(35)\end{array}$ & $\begin{array}{l}38.6 \\
(81)\end{array}$ & $\begin{array}{l}40 \\
(84)\end{array}$ \\
\hline
\end{tabular}

Note. Numbers in bracket indicate frequencies

Table 8 shows that Passion for Work trait was the most frequently practiced creative trait as demonstrated by the principals with the highest percentage $(94.3 \%)$ as fairly often and very frequently. This was followed by Flexibility (90\%). Goal Setting came in the third stage with 89.1 percent followed by Originality with a similar percentage of 88.1 percent. In fifth was Intelligence $(84.3 \%)$. Independence came next $(82.9 \%)$ followed in seventh place by Motivation trait with 78.6 percent. Finally, Wide Range of Interests came lowest with 75 percent.

Interestingly, it is clear that principals display a Passion for Work, this creative trait being given the highest percentage. Passion for Work is considered an important element for enhancing creativity in schools. It can be noted also that principals were perceived to be flexible when dealing with teachers and when solving school problems. Flexibility encourages people to do things creatively and makes them more receptive to new ideas.

However, the creative trait of Motivation was perceived to be less frequently displayed by the principals. It is clearly not enough for the principals to have passion for work alone, but they have to transfer this passion to their teachers by motivation and proper encouragement. 


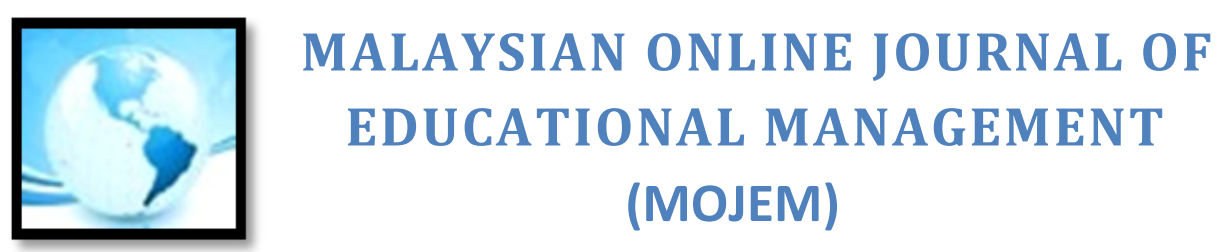

- $\quad$ Teachers' Perceptions of Principals' Creativity Traits by Dimension

Analysis of the results from the Creativity Teacher Observation Questionnaire (CTOQ) shows that teachers perceived their principals positively in all creativity traits with slightly lower percentages than principals perceived themselves. The percentages ranged from 71.1 percent (the lowest) to 86.4 percent (the highest) and it is acceptable overall. While the trait of Wide Range of Interests got the lowest percentage, Passion for Work was perceived by teachers as the highest. Details of the teachers' perceptions for the eight creativity traits of their principals are displayed in Table 9.

As shows in Table 9, the results show that the Passion for Work trait was also the first among the creativity traits to be demonstrated fairly often or very frequently by principals as perceived by their teachers and got the highest percentage $(86.4 \%)$. This was followed by Goal Setting with a percentage of 82.2 percent. Originality came in third with a percentage of 80.5. Independence came next with 77.9 percent followed by Motivation with a similar percentage $(76.9 \%)$. Flexibility came in the sixth stage with the percentage of 75.4 percent followed by Intelligence with 74.4 percent. Wide Range of Interests was the final trait that got 71.1 percent.

Table 9

Teachers' Perceptions of Principals' Creativity Traits by Dimension ( $\mathrm{N}=889)$

\begin{tabular}{llllll}
\hline Traits & Rarely & $\begin{array}{l}\text { Once in a } \\
\text { While }\end{array}$ & $\begin{array}{l}\text { Some } \\
\text { times }\end{array}$ & $\begin{array}{l}\text { Fairly } \\
\text { Often }\end{array}$ & $\begin{array}{l}\text { Very } \\
\text { Frequently }\end{array}$ \\
\hline Passion for Work & 1.3 & 2.8 & 9.4 & 33.8 & 52.6 \\
& $(35)$ & $(75)$ & $(251)$ & $(902)$ & $(1404)$ \\
Independence & 3.1 & 3.1 & 15.9 & 34.5 & 43.4 \\
& $(83)$ & $(83)$ & $(423)$ & $(920)$ & $(1158)$ \\
Goal Setting & 2 & 2.8 & 13 & 37.7 & 44.5 \\
& $(52)$ & $(76)$ & $(347)$ & $(1006)$ & $(1186)$ \\
Originality & 2.2 & 3.6 & 13.5 & 31.5 & 49 \\
& $(60)$ & $(96)$ & $(361)$ & $(840)$ & $(1310)$ \\
Flexibility & 3.1 & 4.8 & 16.7 & 40 & 35.4 \\
& $(81)$ & $(127)$ & $(446)$ & $(1070)$ & $(943)$ \\
Wide Range of Interests & 3.7 & 5.6 & 19.6 & 36.8 & 34.3 \\
& $(66)$ & $(99)$ & $(349)$ & $(655)$ & $9609)$ \\
Intelligence & & & & & \\
& 2.4 & 5.1 & 18.1 & 38 & 36.4 \\
& $(43)$ & $(91)$ & $(321)$ & $(676)$ & $(647)$ \\
Motivation & & & & & \\
& 2.7 & 4.7 & 15.7 & 31.8 & 45.1 \\
& $(73)$ & $(124)$ & $(420)$ & $(848)$ & $(1202)$ \\
\hline & & & & &
\end{tabular}


It is interesting to note that teachers felt their principals' Passion for Work as this trait was perceived as the most frequently practiced. This may reflect positively on the teachers' spirit and feelings. Teachers also noted that principals do care about Goal Setting as a means to help people to be systematic and creative. However, it can be noted that teachers do not always receive motivation from their principals and do not perceive their principals as being flexible all the time.

\section{The Relationship between the Leadership Practices of Principals and Their Creativity Traits at the Islamic Schools}

The data related to the third research question were obtained from principals' and teachers' responses to the Leadership Practices Inventory (LPI-Self) and (LPI-Observer) and Creativity Self-Perception Questionnaire (CSPQ) and Creativity Teacher Observation Questionnaire (CTOQ). To answer this question, Pearson's correlation analysis was used between the final results of the ten leadership dimensions and the eight creativity traits of principals and then between each dimension of the ten leadership practices and the eight creativity traits of principals.

\section{- $\quad$ Relationship between leadership dimensions and creativity traits according to the principals' perceptions}

As presents in Table 10, analysis of the results of the Pearson correlation from the Leadership Practices Inventory (LPI-Self) and Creativity Self-Perception Questionnaire (CSPQ) revealed that the correlation between the results of the ten leadership dimensions together and the eight creativity traits of principals was positively significant with $r$ $=.35, p<.01$ according to the principals' perceptions about themselves.

Table 10

The Relationship between the Leadership Dimensions and the Creativity Traits According to the Principals' Perceptions

(N=70) Leadership Practices

\begin{tabular}{ll}
\hline Creativity Traits & Correlation \\
$.35^{* *}$ \\
\hline
\end{tabular}

Note. ${ }^{* *} P<.01$

This relationship means that wherever the ten leadership dimensions are found, the creativity traits will be identified and vice versa. In other words, the principals who are exhibiting the leadership dimensions will easily display the creativity traits and vice versa. This proposed that the more leadership dimensions principals practice, the more creative they are.

- $\quad$ Relationship between leadership dimensions and creativity traits according to teachers' perceptions

As shows in Table 11, the results of the Pearson correlation from the Leadership Practices Inventory (LPI- Observer) and Creativity Teacher Observation Questionnaire (CTOQ) that provides the teachers' perceptions of principals revealed that the correlation between the ten leadership dimensions and the eight creativity traits of principals is positive and significant with $r=.48, p<.01$ according to the teachers' perceptions of their principals. 


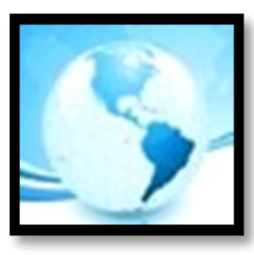

Table 11

The Relationship between the Leadership Dimensions and the Creativity Traits According to the Teachers' Perceptions

\begin{tabular}{|c|c|}
\hline$(\mathrm{N}=889)$ & Leadership Practices \\
\hline \multirow[t]{2}{*}{ Creativity Traits } & Correlation \\
\hline & $0.48 * *$ \\
\hline
\end{tabular}

This relationship means that, wherever the ten leadership dimensions are found, the creativity traits will be identified and vice versa. In other words, the results supported the idea that principals who are exhibiting the leadership dimensions will be ready to practice the creativity traits and vice versa. This proposed that the more leadership dimensions principals practice, the more creative they are, as perceived by the teachers.

As the relationship between the leadership dimensions and the creativity traits were elaborated in the previous section according to the principals' perception, it will be limited in this section as the relationship is same whether perceived by the principals or by their teachers.

\section{CONCLUSIONS}

As educational Muslims, the exposition of Islamic educational leadership and creativity are timely and justified. This goal will be achieved by examining the Islamic schools in general. Islamic schools in Jordan were studied as an example to help understanding the Islamic framework of leadership and creativity.

The results of this study show that principals of Islamic schools should understand their role as visionary, servant and influential leader. They have to also consider themselves as a model to rest of the school's personnel and the local community. In addition, they have the responsibility to develop the staff, to improve themselves to be satisfied on the existing achievements.

The findings indicate that principals should also practice 'brotherhood, collaborative, shuratic or consultative and supportive leadership'. Looking at the school staff as brothers and sisters in Islam before being employees will motivate people and encourage them to strive for excellence, achieve outstanding results and maintain high levels of cooperation. On the other hand, practicing shura at the school will make staff feel confident and encourage them to support the school philosophy as they feel part of the ownership of the school.

This study managed to examine the leadership dimensions and creativity traits of the principals of the Islamic schools in Jordan. This will help one to better understand the concepts of educational leadership and creativity from an Islamic perspective.

\section{RECOMMENDATIONS}

Although we have dealt with the topic in all earnestness, there are many limitations in terms of knowledge and time framework. Therefore, this work is still far from perfect and complete in studying the Islamic schools in Jordan and discussing the philosophy of educational leadership and creativity in Islam or identifying all the characteristics 


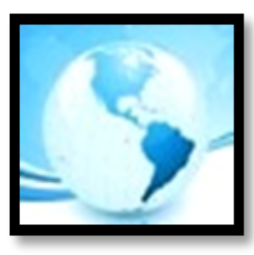

and fundamentals of Islamic educational leadership and creativity. We therefore suggest the following recommendations to enhance the status of Islamic educational leadership and creativity:

- Muslim scholars should make great efforts toward investigating the concepts of Islamic educational leadership and creativity. They have to do more in-depth research on these topics. This will be of assistance in formulating a theory of educational leadership and creativity from the Islamic perspective which contributes to the existing knowledge and engages with it through accommodation or modification.

- The Ministries of education in Muslim nations, Muslim teacher training institutions, Muslim school principals and authorities dealing with Muslim educational institutions should pay a great deal of attention to understanding the concepts of Islamic educational leadership and creativity. As Muslims, they should realize that every aspect in life including administration in educational institutions must be in accordance with Islam.

- Courses on educational leadership in universities, colleges and principals training institutions should incorporate Islamic concepts of educational leadership and creativity. This will enable these institutions to produce sound, knowledgeable and skillful principals and administrators who are able to serve the Muslim Ummah.

- School principals and other educational administrators should practice the Islamic way of leadership. They should consider their work for the sake of Allah as the highest level on their list of priorities. They should be competent and possess good character ( $a k h / a q)$ so that they can be role models for others especially the younger generation.

- Educational leaders should make a great effort to create a sound and healthy environment for their educational organizations. Such an environment will help accomplish the institutional objectives.

- Research centres and leadership institutions should organize seminars, workshops and conferences in order to disseminate the concepts of educational leadership and creativity from an Islamic perspective. This will also help to consolidate and crystallize the Islamic theory of educational leadership and creativity.

- Muslim scholars who are well-versed in Western educational leadership and creativity should increase their efforts in doing comparative studies between the Islamic and Western philosophy of educational leadership and creativity.

- The ten leadership dimensions that have been studied could be a guideline for selecting new principals for the Islamic schools. Creativity traits could be considered as criteria of the school principal evaluation process.

- As the study was focused on the Islamic schools in Jordan, further studies are to be conducted in the Islamic schools in other Muslim countries. This will assist scholars in acquiring a broader view of the current situation in the Islamic schools in Muslims societies. As a result, this will help in fostering understanding of the Islamic theory of leadership.

- As the study was focused on the principals' leadership and creativity and their relationships with the staff, a study could be carried out to focus on the relationship between the leadership dimensions and the students' achievements on one hand and the relationship between the creativity traits of the principals and the students' achievements on the other.

- Similar studies could be conducted to examine the leadership and creativity of other educational leaders such as Ministry of Education personnel, superintendents, school vice principals and other administrative staff.

- A comparative study between Islamic schools and other schools using the same methodology could help us in understanding the unique aspects of the Islamic schools and the main differences between both of them. 


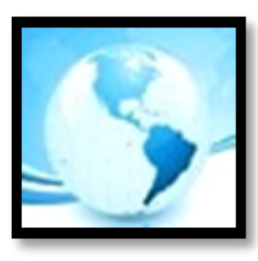

\section{MALAYSIAN ONLINE JOURNAL OF EDUCATIONAL MANAGEMENT (MOJEM)}

\section{REFERENCES}

Abu-Tineh .A. M, Khasawneh. S. A, \& Omary. A.A. (2009). Kouzes and Posner's Transformational Leadership Model in Practice: The Case of Jordanian Schools. Journal of Leadership Education, 7(3), 265-283.

Al-Athm, Y. (2002). Personal interview with the founder of the First Islamic School in Jordan. 23 June 2002. Amman, Jordan.

Al-Dawoud, F. F. S. (1996). Al-Madaris Al-Islamiyyah Al-Khassah fi Al-Ordon [Islamic Private Schools in Jordan]. Master Thesis, University of Yarmouk.

Al-Hammadi, A. (1996). Shararat Al-Ibda' [The Spark of Creativity]. Beirut: Dar Ibn Hazm.

Al-Mazeidy, Z. M. (1993). Moqaddimah fi Manhaj Al-Ibda': Ro'yah Islamiyyah, [An Introduction to the Methodology of Creativity: An Islamic Point of View]. Egypt: Dar Al-Wafa' Littiba'a wa Al-Nashr.

Al-Safi, A. T. (1997). Al-Tafkeer Al-Ibda'l Baina Al-Nathariyyah wa Al-Tatbeeq, [Creative Thinking: A Theory and Practice]. Jeddah: Matabi' Dar Al-Bilad.

Al-Sorour, N. H. (2002). Moqaddimah fi Al-Ibda', [Introduction in Creativity].

Beekun, R., \& Badawi, J.A. (2005). Balancing ethical responsibility among multiple organizational stakeholders: the Islamic perspective. Journal of Business Ethics, 60 (2),131-45.

Datnow, A., \& Castellano, M. E. (2001). Managing and guiding school reform: Leadership in success for all schools. Educational Administration Quarterly, 37, 219-249. http://dx.doi.org/10.1177/00131610121969307

Day, C., Sammons, P., Leithwood, K., Hopkins, D., Harris, A., Gu, Q. \& Brown, E. (2010). Ten strong claims about successful school leadership. Nottingham: NCSL.

Davis, S., Darling-Hammond, L., LaPointe, M., \& Meyerson, D. (2005). School Leadership Study Developing Successful Principals. US: Stanford University School of Education.

Drucker, P. F. (1974). People and performance. London, UK: Heinemann.

Dunford, J., Fawcett, R., \& Bennett, D. (2000). School leadership: National and international perspectives. London, UK: Kogan Page.

Eisawi, A. R. (1990). Saikolojiyyat Al-Ibda': Dirasah fi Tanmiyat Al-Simat Al-Ibda'iyyah [Psychology of Creativity: A Study in the Development of Traits of Creativity]. Beirut: Dar Al-Nahdah Al-Arabiyyah.

Elkhaldi, F. Y. (1994). Islamic schools in Florida: A parental choice. Unpublished Doctoral Dissertation, University of Central Florida.

Goertz, M. J. (1991). The relationship of leader effectiveness and selected traits of creativity. Unpublished Doctoral Dissertation, Northern Arizona University.

Gunter, H. M. (2001). Leaders and leadership in education. London, UK: Paul Chapman. 


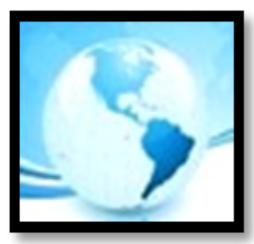

\section{MALAYSIAN ONLINE JOURNAL OF EDUCATIONAL MANAGEMENT (MOJEM)}

Guy, R. F., Edgley, C. E., Arafat, Ibtihaj, \& Allen, D. E. (1987). Social Research methods: Puzzles and solutions. Needham Heights, MA: Allyn and Bacon.

Hallinger.P., \& Huber.S.(2012).School leadership that makes a difference: international perspectives. School Effectiveness and School Improvement: An International Journal of Research, Policy and Practice, 23(4), 359-367.

James, C. \& Vince, R. (2001). Developing the Leadership Capability of Headteachers. Educational Management \& Administration, 29 (3), 307-317.

Johnson, S.M., Donaldson, M., M. Munger, J. Papay, Qazilbash . E.M.(2007). Leading the local: Teachers Union Presidents Speak on Change, Challenges. Washington DC: Education Sector.

Hyatt, K. (2010). The Influence of Leadership Practice Challenging the Process on Perceived Organizational Support. ASBBS Annual Conference, 17(1), 351-361.

Koster-Peterson, L. M. (1993). Leadership skills, practices, and behaviors of effective principals in effective schools. Unpublished doctoral dissertation, Northern Arizona University. 